\title{
PENENTUAN DEWASA MENURUT HUKUM ISLAM DAN BERBAGAI DISIPLIN HUKUM
}

\author{
Nahrowi \\ Fakultas Syariah dan Hukum UIN Syarif Hidayatullah Jakarta \\ Jl. Ir. H. Juanda No. 95 Ciputat Tangerang Selatan \\ Email: nahrowi@uinjkt.ac.id
}

\begin{abstract}
Determining Adulthood according to Islamic Law and Various Disciplines of Law. Each person or legal subject has the legal capacity (rechtsbekwaamheid) or the authority to take legal actions (rechtsbevoegdheid), however, not all legal subjects have the ability and authority to perform legal actions. One of the requirements to be competent in law is adulthood, and it is important to investigate the boundary of adulthood according to various disciplines of law, as well as investigating the influence of the madhabs (schools of jurisprudence) in determining the boundary of adulthood based on each discipline of law. The provision on the boundary of adulthood influences the validity of a person's law actions.
\end{abstract}

Keywords: Legal Subject, Adult Boundaries, Disciplines of Law, Proficient Law, Schools of Jurisprudence

\begin{abstract}
Abstrak: Penentuan Dewasa Menurut Hukum Islam Dan Berbagai Disiplin Hukum. Setiap orang atau subjek hukum mempunyai kecakapan hukum (rechtsbekwaamheid) atau kewenangan untuk melakukan perbuatan hukum (rechtsbevoegdheid), akan tetapi juga tidak semua subjek hukum mempunyai kecakapan serta kewenangan untuk melakukan perbuatan hukum. Salah satu syarat cakap hukum adalah dewasa, dan penting untuk melihat batasan dewasa menurut berbagai disiplin hukum serta pengaruh mazhab hukum dalam penentuan batasan dewasa dari masing-masing disiplin hukum. Ketentuan tentang batasan dewasa berakibat hukum terhadap sah atau tidaknya dia melakukan perbuatan hukum.
\end{abstract}

Kata kunci: Subjek Hukum, Batasan Dewasa, Disiplin Hukum, Cakap Hukum, Mazhab Hukum

\section{Pendahuluan}

Dalam berbagai Disiplin Hukum memiliki pandangan yang berbeda tentang ukuran umur ketika seseorang itu dinyatakan dewasa. Dewasa yang dimaksud adalah umur pada saat orang dinyatakan cakap hukum 
(legal capacity). Tentu setiap disiplin hukum menggunakan terminologi yang berbeda untuk istilah cakap hukum. Sebenarnya setiap orang (person) berarti pembawa hak, yaitu sesuatu yang mempunyai hak dan kewajiban dan disebut subjek hukum. Walaupun menurut hukum, setiap orang tiada terkecuali dapat memiliki hak-hak akan tetapi didalam hukum tidaklah semua orang diperbolehkan bertindak sendiri di dalam melaksanakan hak-haknya itu. Ada beberapa golongan orang yang oleh hukum telah dinyatakan "tidak cakap" atau "kurang cakap" untuk bertindak sendiri dalam melakukan perbuatan-perbuatan hukum (mereka disebut handelingsonbekwaam), tetapi mereka harus diwakili atau dibantu orang lain. ${ }^{1}$

Cakap hukum yang dimaksud adalah apabila seseorang melakukan perbuatan hukum ${ }^{2}$ maka dia dapat dikenakan tindakan hukum tertentu terhadap dirinya. Sebenarnya yang menjadi masalah dalam tulisan ini adalah ingin melihat perbedaan-perbedaan pandangan ketika syarat-syarat seseorang dika takan cakap hukum salah satunya bahwa dia sudah dewasa. Dewasa di sini yang ingin dilihat adalah apakah ada ketentuan batasan umur atau tidak, dan jika ada, berapa batasan umur yang ditentukan oleh masing-masing disiplin hukum, serta pengaruh mazhab hukum apa dalam penentuan batasan dewasa tersebut.

Dalam tulisan ini akan dibagi 3 bahasan pokok; pertama tentang "Penentuan Batasan Dewasa", kedua tentang "Pokok-pokok pendapat mazhab hukum dan tokoh-tokoh utamanya", ketiga tentang "Kesimpulan atau Penutup, yaitu Mazhab mana yang mempengaruhi penentuan batasan dewasa”.

\section{Penentuan Batasan Dewasa}

\section{Sudut Pandang Hukum Perdata}

Pasal 1330 juncto 330 Kitab Undang-undang Hukum Perdata (KUHPerdata) melalui interpretasi contrario dinyatakan: "Tak cakap untuk membuat suatu perjanjian adalah; (1). Orang-orang yang belum dewasa;

\footnotetext{
${ }^{1}$ Kansil, Pengantar Ilmu Hukum, (Jakarta: Balai Pustaka, 1999), h. 85.

2 Kata "perbuatan hukum" adalah untuk membedakan dengan kata "perbuatan" saja, karena perbuatan hukum adalah suatu perbuatan yang apabila dilakukan oleh seseorang maka dapat menimbulkan akibat-akibat hukum. Akibat-akibat hukum dalam disiplin hukum memiliki ketentuan yang berbeda-beda.
} 
(2). Mereka yang ditaruh di bawah pengampuan; (3). Orang-orang perempuan, dalam hal-hal yang ditetapkan oleh undang-undang, dan pada umumnya semua orang kepada siapa undang-undang telah melarang membuat perjanjian-perjanjian tertentu". ${ }^{3}$

Kemudian penjelasan arti dewasa di tuangkan dalam pasal 330 KUHPerdata yang berbunyi: "Belum dewasa adalah mereka yang belum mencapai umur genap dua puluh satu tahun, dan tidak lebih dahulu telah kawin". Ketentuan pasal-pasal ini dapat ditafsirkan secara terbalik atau disebut Penafsiran Contrario, maka maksudnya menjadi: cakap melakukan perbuatan hukum dengan syarat-syarat sebagai berikut: (1)Dewasa; (2) Tidak di bawah pengampuan (curatele); (3) Orang-orang perempuan.

Pengertian dewasa adalah orang yang telah berumur 21 tahun atau telah kawin sebelum usia 21 tahun. Gila juga meyebabkan orang tidak cakap melakukan perbuatan hukum. Cakap melakukan perbuatan hukum juga terdapat dalam pasal 1320 KUHPerdata, yaitu: "Untuk sahnya suatu perjanjian diperlukan empat syarat; (1). sepakat mereka yang mengikatkan dirinya; (2). kecakapan untuk membuat suatu perikatan; (3). suatu hal tertentu;(4). suatu sebab yang halal.

Syarat (1) dan (2) disebut syarat Subjektif karena menyangkut pelaku perjanjian dan konsekwensinya jika tidak dipenuhi keduanya atau salah satunya maka "dapat dimintakan pembatalan", sedangkan syarat (3) dan (4) disebut syarat Objektif karena menyangkut Objek perjanjian dan konsekwensinya "batal demi hukum"

Dalam Hukum Perdata tertuang dalam pasal 330 KUHPerdata bahwa "Belum dewasa adalah mereka yang belum mencapai umur genap dua puluh satu tahun, dan tidak lebih dahulu telah kawin. Apabila perkawinan itu dibubarkan sebelum umur mereka genap dua puluh satu tahun, maka mereka tidak kembali lagi dalam kedudukan belum dewasa". ${ }^{4}$

Jelas sekali bahwa dewasa dalam arti bagian dari syarat-syarat cakap hukum atau apabila seseorang melakukan perbuatan hukum dan dapat menimbulkan akibat hukum baik timbul hak dan kewajiban para pihak

\footnotetext{
${ }^{3}$ Ketentuan huruf c telah dihapus oleh pasal 31 UU Nomor 1 Tahun 1974 tentang Perkawinan yang pada intinya menyatakan bahwa suami isteri mempunyai kedudukan seimbang dan dapat melakukan perbuatan hokum masing-masing.

${ }^{4}$ Pelu di ingat bahwa usia kawin di sini adalah sesuai dengan pasal 29 KUHPerdata, yaitu bagi laki-laki telah berusia 18 tahun dan bagi wanita telah berusia 15 tahun.
} 
ataupun dapat digugat ke muka pengadilan maka harus telah berusia 21 tahun atau telah kawin sebelum usia 21 tahun.

Berbeda dengan Undang-Undang Nomor 1 Tahun 1974 tentang Perkawinan yang biasa disebut UU Perkawinan (UUP), yang sekalipun berjudul UU tentang Perkawinan, tetapi di dalamnya diatur juga hukum keluarga, dan sekalipun tidak secara tegas-tegas mengatur "umur dewasa", tetapi ada ketentuan dimana dapat disimpulkan batas umur dewasa menurut UU Perkawinan, yaitu dari pasal 47 dan pasal 50 UUP, bahwa UUP berpegang pada patokan umur dewasa 18 tahun. Kalau UUP menetapkan kewenangan orang tua dan wali untuk mewakili anak belum dewasa, berakhir pada saat anak mencapai usia 18 tahun (atau setelah menikah sebelumnya) maka tidak logis kalau UUP mempunyai patokan usia dewasa lain daripada 18 tahun. Karena kekuasaan orang tua dan perwalian berkaitan dengan masalah kecakapan bertindak, maka dengan demikian menurut UUP orang yang sudah mencapai umur genap 18 tahun telah dewasa, dengan konsekuensinya telah cakap untuk bertindak dalam hukum (yang menarik perlu di kaji secara lebih dalam lagi nantinya adalah UUP bersifat nasional, lihat bagian menimbang UUP, "Bahwa sesuai dengan falsafah Pancasila serta cita-cita untuk pembinaan hukum nasional, perlu adanya Undang-Undang Perkawinan yang berlaku bagi semua warga negara").

\section{Sudut Pandang Hukum Pidana}

Dalam hukum pidana usia dewasa adalah 18 tahun. Ketentuan ini dapat kita simpulkan berdasarkan pasal 45 dan 46 Kitab Undang-undang Hukum Pidana (KUHP), bahwa mereka yang belum cukup umur (minderjarig) adalah yang belum berusia 18 tahun (16 tahun di tambah 2 tahun) dan ada pengaturan khusus tentang pengurangan maksimum pidana pokok terhadap perbuatan pidananya dikurangi sepertiga.

Jika dibandingkan dengan Undang-undang Nomor 3 Tahun 1997 tentang Pengadilan Anak dan Undang-undang Nomor 23 Tahun 2000 tentang Perlindungan Anak maka yang disebut anak adalah "Seorang yang belum berusia 18 (delapan belas) tahun, termasuk anak yang masih dalam kandungan". ${ }^{5}$

\footnotetext{
${ }^{5}$ Ahmad Kamil dan H.M. Fauzan, Hukum Perlindungan dan Pengangkatan Anak di Indonesia,
} 
Usia dewasa dalam Hukum Pidana adalah mereka yang telah memasuki usia 18 tahun, sedangkan jika cakap hukum, artinya seseorang dapat diancam hukum pidana Indonesia adalah seseorang yang telah berumur 18 tahun dan memang sehat akal pikirannnya. Tentu ada syarat syarat lain, namun yang perlu diperhatikan adalah ketika seseorang telah berusia 18 tahun maka tidak ada perlakuan-perlakuan khusus jika dia melakukan tindak pidana. Mereka yang telah berumur 18 tahun dapat dijatuhi sanksi pidana jika melakukan perbuatan pidana. Adapun sanksi tersebut dapat berupa:

1) Pidana Pokok;
a) Pidana mati;
b) Pidana penjara;
c) Kurungan;
d) Denda.

2) Pidana Tambahan:

a) Pencabutan hak-hak tertentu;

b) Perampasan barang-barang tertentu;

c) Pengumuman putusan hakim. ${ }^{6}$

Berbeda dengan seorang yang belum berumur 18 tahun maka disebut anak. Bagi anak yang melakukan perbuatan pidana atau disebut "anak nakal" maka diatur dalam ketentuan khusus yang disebut dengan Undangundang Nomor 3 Tahun 1997 tentang Pengadilan Anak.

Sanksi bagi anak nakal adalah: (1)Dikembalikan kepada orang tua; (2) Diserahkan kepada Negara; (3) Diserahkan kepada Departemen Sosial atau Organisasi Sosial Kemasyarakatan. ${ }^{7}$

\section{Sudut Pandang Hukum Ketatanegaraan}

Hukum Ketatanegaraan yang dimaksud adalah mengambil ruang lingkup Hukum Tata Negara yaitu struktur negara atau struktur pemerintahan yang terdiri dari kekuasaan Legislatif, Eksekutif dan Yudikatif.

(Jakarta: PT. Raja Grafindo Persada, 2008), h. 378.

${ }^{6}$ Moeljatno, Kitab Undang-undang Hukum Pidana, (Jakarta: Bumi Aksara, 1996), h. 5-6.

${ }^{7}$ Darwan Prist, Hukum Anak Indonesia, (Bandung: PT. Citra Aditya Bakti, 2003), h. 28-29.

${ }^{8}$ M. Solly Lubis, Asas-Asas Hukum Tata Negara, (tp, 1972), h. 28. 
Maksud dari sudut pandang Hukum Ketatanegaraan adalah ketika seseorang dapat menyalurkan hak politiknya untuk memilih melalui Pemilihan Umum, baik pemilihan kepala daerah, DPR/DPRD (Legislatif) ataupun Presiden dan Wakil Presiden (Eksekutif).

Usia dewasa yang dimaksud di atas adalah telah berusia 17 tahun. Dalam pasal 19 Undang-undang Nomor 2008 tentang Pemilihan Umum Anggota DPR, DPD dan DPRD dinyatakan "warga Negara Indonesia yang pada hari pemungutan suara telah genap berumur 17 (tujuh belas) tahun atau lebih atau sudah/pernah kawin mempunyai hak memilih"9

Artinya, orang yang telah berumur 17 tahun dapat melakukan atau menyalurkan hak politiknya untuk memilih Calon Legislatif (DPR/ DPRD/DPD) dan Presiden atau Wakil Presiden. Selain telah berusia 17 tahun tentu ada persyaratan lain yang ditentukan dalam Undang-undang PEMILU, terutama undang-undang pemilihan baik DPR/DPRD/DPD dan Presiden dan Wakil Presiden tahun 2009 yang baru saja dilaksanakan.

Usia dewasa sudut pandang Hukum Ketatanegaraan juga dapat dilihat dalam pasal 63 Undang-undang Nomor 23 Tahun 2006 tentang Administrasi Kependudukan bahwa: "Penduduk Warga Negara Indonesia dan Orang asing yang memiliki Izin tinggal Tetap yang telah berumur 17 (tujuh belas) tahun atau telah kawin atau pernah kawin wajib memiliki KTP”.

Untuk orang asing adalah orang asing yang mengikuti status orang tuanya yang memiliki Izin Tinggal Tetap dan sudah berumur 17 tahun wajib memiliki KTP. Bagi Warga Negara Asing yang bukan ada hubungan keturunan dan ingin menjadi Warga Negara Indonesia maka harus menunggu usia 18 tahun. ${ }^{10}$

Dengan memiliki Kartu Tanda Penduduk, seseorang dapat memperoleh hak lanjutan, seperti; memiliki Surat Izin Mengemudi, Pasport dan perbuatan hukum lainnya yang memerlukan persyaratan KTP.

Seseorang atau penduduk yang tidak mempunyai KTP dan melakukan perbuatan hukum dengan cara memalsukan KTP dapat dikenakan sanksi Administratif atau ketentuan Pidana sebagaimana dalam 89 sampai dengan pasal 98 UU Nomor 23 Tahun 2006 tentang Administrasi Kependudukan.

${ }^{9}$ Undang-undang PEMILU, (Surabaya: Kesindo Utama, 2008), h. 15.

${ }^{10}$ Lihat pasal 9 Undang-undang Nomor 12 Tahun 2006 tentang Kewarganegaraan Republik Indonesia. 


\section{Sudut Pandang Hukum Islam}

Mahkum 'Alaih adalah orang-orang mukallaf yang di bebani hukum. Abdul Wahhab Khallaf menerangkan bahwa Mahkum Alaih adalah orangorang mukallaf yang di bebani hukum syara' dengan perbuatannya.

Chairul Umam berpendapat jika di lihat dari aspek kebahasaan, Mahkum Alaih memberi makna seseorang yang perbuatannya dikenai kitab Allah SWT, yakni orang yang dibenani hukum mukallaf, dalam istilah Ushul Fikih mukallaf sering disebut dengan subjek hukum.

Orang mukallaf adalah orang yang telah dianggap mampu bertindak hukum, baik yang berhubungan dengan perintah Allah maupun dengan laranganNya. Ia telah dibebani dengan kewajiban, larangan, anjuran, dan berbagai kewajiban lainnya sehingga bila bersalah maka ia akan dibebani hukuman-hukuman sesuai dengan yang di kerjakannya. Adapun mengenai sah tidaknya membebani hukum kepada mukallaf, maka dalam syara' di syaratkan dengan dua syarat:

a. Bahwa ia haruslah mampu mentaklifkan dalil pentaklifan, sebagaimana ia mampu untuk memahami berbagai nash perundang-undangan yang ditaklifkan padanya dalam Al-Qur'an dan Sunnah, baik dengan sendirinya atau dengan perantaraan. Karena sesungguhnya orang yang tidak sanggup memahami dalil pentaklifkan, maka ia tidak mungkin untuk melaksanakan sesuatu yang ditaklifkan padanya, dan tidak bisa pula mengarahkan maksudnya kepadanya. Kemampuan untuk memahami dalil-dalil taklif hanyalah dapat dibuktikan dengan akal dan keberadaan nash yang ditaklifkan pada orang-orang yang berakal pada jangkauan akal mereka untuk memahaminya, sebab sesungguhnya akal adalah alat memahmi dan menangkap, dan dengan akal pulalah keinginan untuk mengikuti perintah dapat diarahkan. Karena akal adalah suatu hal yang abstrak yang tidak dapat ditangkap dengan penginderaan yang konkrit, maka Syari' menkaitkan pentaklifan dengan hal yang konkrit yang dapat ditangkap dengan penginderaan yang menjadi tempat dugaan keberakalan, yaitu keadaan baligh. Jadi barang siapa yang telah mencapai baligh, tanpa kelihatan adanya halhal baru yang merusak kemampuan akalnya, maka pada dirinya telah terpenuhi kemampuan untuk taklif. Berdasarkan persyaratan ini, maka orang yang gila tidak terkena taklif, demikian pula anak kecil, karena ketiadaan akal yang menjadi sarana untuk memahami dalil taklif. 
Orang yang ghafil (lalai), orang yang tidur, dan orang yang mabuk juga tidak terkena taklif, karena sesungguhnya mereka dalam keadaan lalai, tidur, atau mabuk, yang tidak mampu untuk memahami. Oleh karena inilah, maka Rasulullah saw, bersabda : "Catatan amal diangkat dari tiga jenis orang, yaitu: orang yang tidur sampai ia bangun, dari anak kecil sampai ia dewasa, dan dari orang yang gila sampai ia berakal. ${ }^{11}$

b. Mukallaf haruslah layak untuk dikenakan taklif. Selain itu, mukallaf adalah orang yang ahli dengan sesuatu yang di bebankan kepadanya. Secara bahasa menurut para ahli adalah kelayakan atau layak (seperti bila) dikatakan, "fulan adalah ahli (layak) memelihara wakaf", artinya ia adalah orang yang pantas dan layak di bebani hukum seperti tidak gila dan sudah balig.

Sedangkan menurut ulama Ushul: Ahli (layak) itu terbagi kepada dua bagian yaitu: Ahli Wajib dan Ahli Melaksanakan. ${ }^{12}$.

a. Ahli Wajib yaitu kelayakan seseorang untuk ada padanya hak-hak dan kewajiban. Ahli keahlian (kelayakan) ini ialah kekhususan yang diciptakan oleh Allah SWT kepada manusia dan menjadi kekhususannya diantara macam-macam binatang. Dengan keahlian itu dia layak menerima hak dan kewajiban. Kekhususan inilah disebut Adz-Dzimah yaitu sifat naluri kemanusiaan yang dengan itu manusia menerima ketetapan hak-hak bagi orang lain dan menerima kewajiban untuk orang lain pula.

Keahlian inilah (Ahli Wajib) yang tetap bagi setiap manusia dengan keadaan bahwa dia itu adalah manusia, baik lelaki maupun perempuan, baik janin (masih dalam kandungan) atau kanak-kanak, atau anak yang sudah mumayyiz atau sudah baligh atau dewasa, punya akal atau gila dan sehat atau sakit. Karena keahlian ini didasarkan atas kekhususan naluri kemanusiaan. Jadi setiap manusia mana saja dia mempunyai keahlian (kelayakan) wajib.Tidak ada manusia yang lepas dari itu, karena keahlian wajib itulah sebagai sifat kemanusiaannya.

Jadi Ahliyyah Al-wujub itu adalah kelayakan seseorang untuk ada padanya dalam keputusan seseorang untuk menerima haknya dari orang lain dan memenuhi kewajiban kepada orang lain.

${ }^{11}$ Abdul Wahhab Khallaf, Ilmu Ushul Figh, Semarang: Toha Putra Group, 1994, h. 199

${ }^{12}$ Muliadi Kurdi, Ushul Figh, Aceh :Lembaga Naskah Aceh (Nasa), 2015, h. 322-324 
Para Ahli Ushul Fikih membagi Ahliyyatul Wujub pada 2 tingkatan:

1. Ahliyyah Al-wujub Al-naqisoh atau kecakapan dikenai hukum secara lemah, yaitu kecakapan seorang manusia untuk menerima hak, tetapi tidak menerima kewajiban, atau kecakapan untuk dikenai kewajiban tetapi tidak pantas menerima hak.

Contoh kecakapan untuk menerima hak, tetapi tidak untuk menerima kewajiban adalah bayi dalam kandungan ibunya, bayi itu telah berhak menerima hak kebendaan seperti warisan dan wasiat, meski ia belum lahir. Realisasi dari hak itu berlaku setelah ia lahir dalam keadaan hidup. Bayi dalam kandungan itu tidak dibebani kewajiban apa-apa karena secara jelas ia belum bernama manusia.

Contoh kecakapan untuk dikenai kewajiban tetapi tidak cakap menerima hak adalah orang yang telah mati tapi masih meninggalkan hutang, dengan kematiannya itu .ia tidak akan mendapatkan hak apa-apa lagi, tetapi masih dikenakan kewajiban untuk membayar hutang.

2. Abliyyah Al-wujub Al-kamilah atau kecakapan dikenai hukum secara sempurna, yaitu kecakapan seseorang untuk dikenai kewajiban dan juga untuk menerima hak.

Contohnya adalah anak yang baru lahir, disamping ia berhak menerima harta warisan, ia juga telah dikenai kewajiban seperti membayar zakat fitrah yang pelaksanaannya dilakukan oleh orang tua/wali bayi tersebut. ${ }^{13}$

b. Ahli Melaksanakan (Abliyyatul Al-ada)

Yaitu kelayakan mukallaf untuk dianggap ucapan-ucapan dan perbuatanperbuatannya menurut syara', sekira apabila keluar daripadanya akad (kontrak) atau tasharruf (pengelolaan), maka menurut syara' akad atau tasharruf itu bisa diperhitungkan adanya, dan terjadinya tertib hukum atasnya. Apabila mukallaf mendirikan sholat, atau berpuasa, atau melaksanakan ibadah haji, atau mengerjakan kewajiban apa saja, maka semua itu menurut syara' bisa diperhitungkan (di i'tibar), dan bisa menggugatkan kewajiban mukallaf. Dan apabila mukallaf berbuat pidana atas orang lain dalam soal jiwa, harta, kehormatan, maka

13 http://s3.amazonaws.com/academia.edu.documents/46794905/HAKIM_DAN_ MUKALLAF.pdf 
dia dihukum sesuai dengan pidananya dan diganjar atas pidananya itu dengan bentuk fisik dan harta. Maka "Ahli Al-ada" itulah yang dimintai pertanggung jawaban, sedangkan asasnya dalam manusia adalah membedakan akal. ${ }^{14}$

Kecakapan untuk menjalankan hukum (Abliyyah Al-ada) yaitu kepantasan seseorang manusia untuk diperhitungkan segala tindakannya menurut hukum. Kecakapan berbuat hukum (ahliyyatul ada') terdiri dari tiga tingkat, setiap tingkat ini dikaitkan kepada batas umur manusia. Ketiga tingkat tersebut adalah: (1) Adim Al-ahliyyah atau tidak cakap sama sekali yaitu manusia semenjak lahir sampai mencapai umur tamyis sekitar umur 7 tahun. (2) Abliyyah Al-ada' Al-naqisoh atau cakap berbuat hukum secara lemah, yaitu manusia yang telah mencapai umur tamyis (kira-kira umur 7 tahun) smpai batas dewasa. (3)Abliyyah Al-ada' Al-kamilah atau cakap berbuat hukum secara sempurna, yaitu manusia yang telah mencapai usia dewasa. ${ }^{15}$

\section{a. Tanda-tanda balig untuk laki-laki antara lain:}

1). Ihtilam, yaitu keluarnya mani baik karena mimpi atau karena lainnya. Dalilnya antara lain adalah:

a). Firman Allah táala:

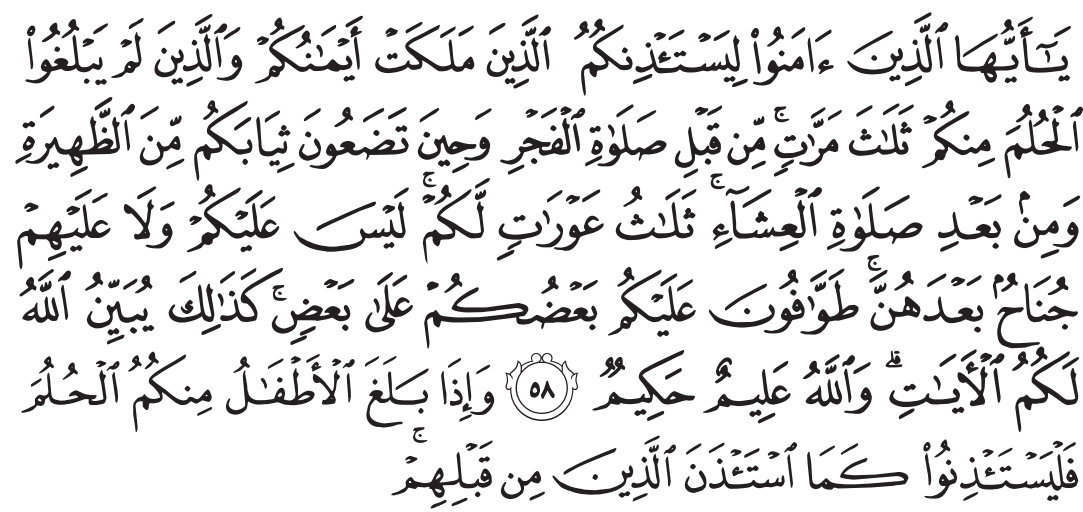

"Hai orang-orang yang beriman, hendaklah budak-budak (lelaki dan wanita) yang kamu miliki, dan orang-orang yang belum mencapai

${ }^{14}$ Abdul Wahhab Khallaf, Kaidah-kaidah Hukum Islam (Ilmu Ushulul Fiqh), Jakarta:PT. RajaGrafindo Persada, 2000, h.210-211

${ }^{15}$ Syarifuddin Amir. Ushul Figh Jilid 1. Jakarta: PT. Logos Wacana Ilmu. 2000, h. 55 
"hulm" (ihtilaam) di antara kamu, meminta izin kepada kamu tiga kali (dalam satu hari) yaitu: sebelum sembahyang subuh, ketika kamu menanggalkan pakaian (luar)-mu di tengah hari dan sesudah sembahyang Isya. (Itulah) tiga 'aurat bagi kamu. Tidak ada dosa atasmu dan tidak (pula) atas mereka selain dari (tiga waktu) itu. Mereka melayani kamu, sebahagian kamu (ada keperluan) kepada sebahagian (yang lain). Demikianlah Allah menjelaskan ayat-ayat bagi kamu. Dan Allah Maha Mengetahui lagi Maha Bijaksana. Dan apabila anak-anakmu telah sampai "hulm" (ihtilaam/usiabalig), maka hendaklah mereka meminta izin, seperti orang-orang yang sebelum mereka meminta ijin" (QS. An-Nuur : 59).

Segi pendalilan dari ayat ini adalah bahwa hulm (ihtilam) dijadikan batas kewajiban bagi seorang anak untuk meminta ijin di semua waktu ketika ia hendak memasuki kamar orang tuanya. Ini adalah asal hukum dalam minta ijin (yaitu minta ijin sebelum masuk). Berbeda halnya ketika ia belum mencapai hulm, maka ia hanya dibebankan meminta ijin di tiga waktu saja, dan tidak mengapa baginya jika ia masuk (tanpa ijin) di selain tiga waktu tersebut.

b) Dari Abu Sa'id Al-Khudriy $R A$ : Bahwasannya Rasulullah SAW pernah bersabda:

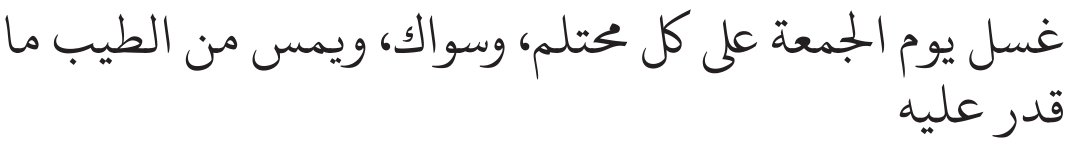

"Mandi pada hari Jum'at (sebelum menunaikan shalat Jum'at) adalah kewajiban bagi setiap orang yang telah ihtilam; demikian pula bersiwak dan memakai wewangian semampunya" 16

Ihtilaam dijadikan batas taklif dalam syariat. Begitu pula dengan hadis-hadis di bawah:

c) Dari Ali (bin Abi Thaalib) $R A$, dari Nabi Muhammad SAW, beliau bersabda:

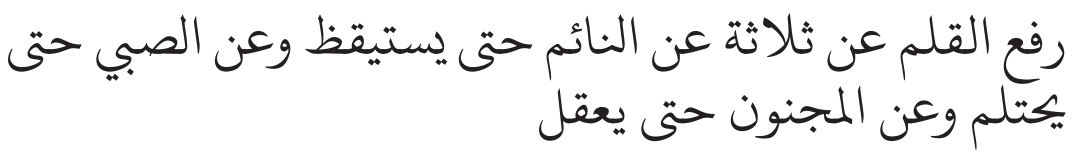

${ }^{16}$ 11. AlBukhaari, Sohih AlBukhaari, h. 880, dan Sohih AlMuslim, h. 846 
"Diangkat pena (tidak dikenakan kewajiban) pada tiga orang, yaitu: orang yang tidur hingga bangun, anak kecil hingga ihtilam, dan orang gila hingga berakal”. (HR. Abu Dawud)

d) Dari Mu'adz $R A$ :

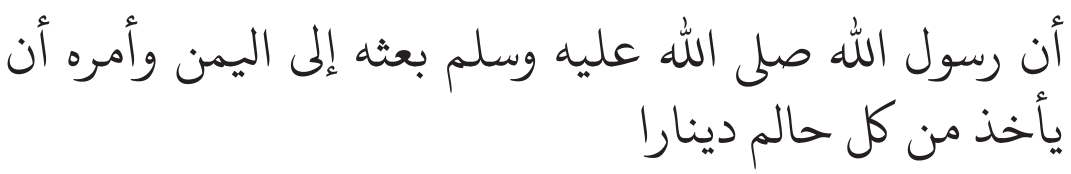

"Bahwasannya Rasulullah SAW mengutusnya ke Yaman dan memerintahnya untuk mengambil dari setiap orang yang telah ihtilam satu dinar". (HR. An-Nasa'i)

Para ulama telah sepakat bahwa ihtilam merupakan tanda kedewasaan bagi anak laki-laki dan perempuan. Al-Haafidh Ibnu Hajar rahimahullah berkata:

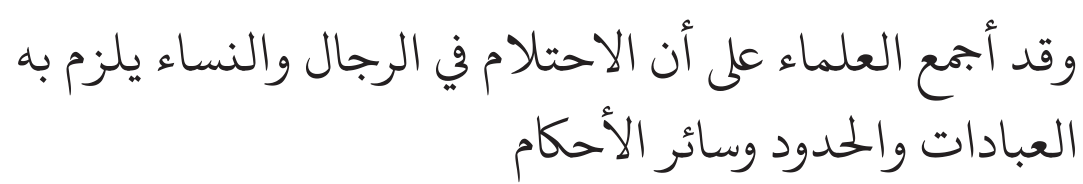

"Para ulama telah sepakatijma' bahwasannya ihtilaam pada laki-laki dan perempuan mewajibkan dengannya (untuk diberlakukannya) ibadah, hudund, dan seluruh perkara hukum" ${ }^{17}$.

2). Tumbuhnya Rambut Kemaluan.

Para ulama berbeda pendapat mengenai hal ini. Madzhab Hanafiyyah berpendapat bahwa tumbuhnya rambut kemaluan bukan merupakan tanda balig secara mutlak ${ }^{18}$. Madzhab Hanabilah dan satu riwayat dari Abu Yusuf dari Madzhab Hanafiyyah berpendapat bahwa tumbuhnya rambut kemaluan merupakan tanda balig secara mutlak ${ }^{19}$

Madzhab Malikiyyah terpecah menjadi dua pendapat. Pendapat pertama mengatakan bahwa tumbuhnya rambut kemaluan merupakan tanda balig secara mutlak, dan inilah pendapat yang masyhur dalam mazhab maliki, Pendapat kedua mengatakan bahwa ia merupakan tanda balig yang menyangkut hak-hak anak Adam dalam beberapa hukum seperti qadzaf (menuduh wanita baik-baik telah berbuat zina),

\footnotetext{
${ }^{17}$ Ibnu Hajar Al Asqolani, Fathul Barii, Juz 5 h. 277

${ }^{18}$ Abi Said, Roddul Mubktar, Juz 5 h. 97,

${ }^{19}$ Al Nakho'i, Al-Muharrror, Juz 5 h. 277
} 
potong tangan, dan pembunuhan. Adapun yang menyangkut hak-hak kepada Allah táala, maka ia bukan sebagai tanda balig.

Madzhab Syafi'iyyah berpendapat bahwa tumbuhnya rambut kemaluan merupakan tanda balig untuk orang kafir. Adapun bagi muslimin, maka mereka berbeda pendapat. Satu pendapat mengatakan bahwa ia merupakan tanda balig sebagaimana orang kafir, dan pendapat lain yang shahih dalam madzhab-mengatakan bahwa ia bukan tanda balig. ${ }^{20}$

Pendapat yang rajih dari keempat madzhab tersebut adalah pendapat yang mengatakan bahwa tumbuhnya rambut kemaluan merupakan tanda balig secara mutlak bagi muslim atau kafir, baik menyangkut hak Allah atau hak anak Adam. Adapun dalil yang dijadikan hujjah antara lain adalah :

a) Dari 'Athiyyah, ia berkata:

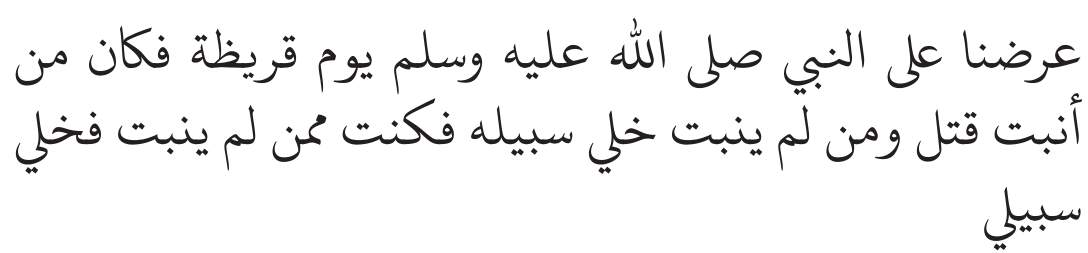

"Kami dihadapkan kepada Nabi shallallaabu 'alaihi wa sallam pada hari Quraidhah (peristiwa pengkhianatan Bani Quraidhah), di situ orang yang sudah tumbuh bulu kemaluannya dibunuh, sedang orang yang belum tumbuh dibiarkan. Aku adalah orangyang belum tumbuh maka aku dibiarkan" (HR. At-Tirmidzi)

b) Dari Samurah bin Jundub bahwasannya Nabi Muhammad SAW bersabda:

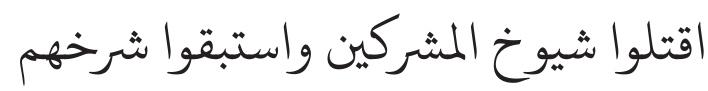

"Bunublah orang-orang tua dari kalangan kaum musyrik dan biarkanlah syark". [HR. Abu Dawud]. Syarkh adalah anak-anak yang belum tumbuh bulu kemaluannya.

Pembedaan antara orang kafir dan orang muslim adalah pembedaan yang sangat lemah. Telah shahih dari Nabi Muhammad SAW larangan membunuh anak-anak orang kafir yang bersamaan

${ }^{20}$ Ali bin Abi Yusuf Asy-Syayrozi, Al-Muhazzab, Juz 1, h. 337-338 
beliau memerintahkan untuk membunuh orang-orang yang telah tumbuh rambut kemaluannya - sehingga dapat dipahami bahwa tumbuhnya rambut kemaluan merupakan tanda balig bagi mereka. Hukumbalig ini bersifat umum lagi mutlak. Oleh karena itu jika seorang imam menangkap dan menghukum seorang pelaku bughat dari kalangan muslimin, maka ia pun hanya boleh membunuh mereka yang telahbalig, tidak pada anak-anak. Dan tanda balig ini dapat diketahui salah satunya dengan tumbuhnya rambut kemaluan pada mereka.

Begitu juga dengan pendapat Malikiyyah yang membedakan antara hak Allah dan hak anak Adam. Jika dikatakan bahwa syariat telah melarang membunuh anak-anak dalam peperangan, maka ini merupakan ketentuan yang datang dari Allah yang harus dipenuhi oleh manusia (kaum muslimin). Tidak bisa dikatakan bahwa menjalankan perintah tersebut adalah sebagai pemenuhan hak anak Adam, bukan pemenuhan hak Allah.

Ibnu Al Qayyim rahimahullah berkata:

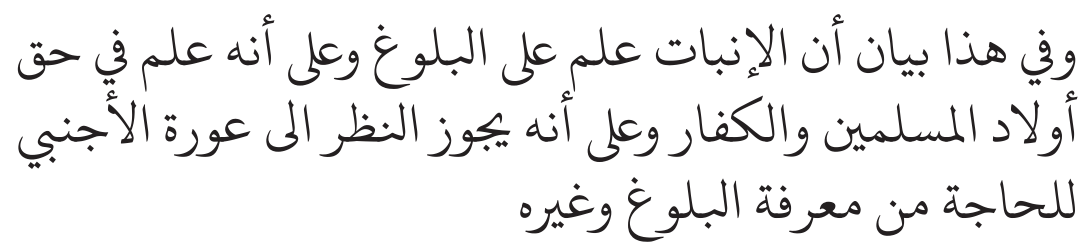

"Dan dalam hal ini terdapat penjelasan bahwa tumbuhnya rambut kemaluan adalah tanda balignya seseorang, bagi anak-anak kaum muslimin dan orang-orang kafir; dan juga menunjukkan bolehnya melihat aurat orang lain bila diperlukan untuk mengetahuibalig dan tidaknya seseorang serta untuk yang lainnya. ${ }^{21}$

3). Mencapai Usia Tertentu.

Para ulama berbeda pendapat mengenai hal ini. Di antara pendapatpendapat tersebut antara lain:

a) Madzhab Syafi'iyyah ${ }^{22}$, dan Hanabilah ${ }^{23}$ serta satu riwayat dari Abu Hanifah yaitu lima belas tahun untuk laki-laki dan perempuan.

\footnotetext{
${ }^{21}$ Ibnu Al Qoyyim, Tuhfatul Maulud bil Ahkam Al-Maulud, h. 210

${ }^{22}$ Imam Abi Zakariya bin Syarof Al Nawawi, Roudoh Al Tolibin, Juz 4, h. 178

${ }^{23}$ Imam Syamsuddin Al Muqoddasi, Al-furuu', Juz 4, h. 312
} 
b) Delapan belas tahun untuk laki-laki dan tujuh belas tahun untuk perempuan $^{24}$

c) Madzhab Malikiyyah, ada beberapa pendapat. Ada yang mengatakan delapan belas tahun untuk laki-laki dan perempuan, sembilan belas tahun, tujuh belas tahun, dan enam belas tahun

d) Ibnu Hazm berpendapat sembilan belas tahun ${ }^{25}$

Dalil yang dianggap paling shahih dan sharih oleh ulama yang memberikan batasan usia yang dibawakan dalam permasalahan ini adalah hadits yang dibawakan oleh pendapat pertama (lima belas tahun) dari Ibnu 'Umar radliyallaahu 'anhuma, ia berkata:

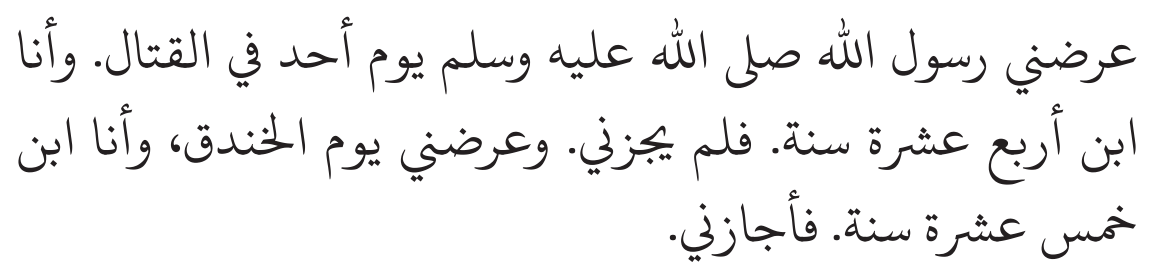

قال نافع: فقدمت على عمر بن عبدالعزيز، وهو يومئذ خليفة. فحدثته هذا الحديث. فقال: إن هذا لحد بين الصغير والكبير. فكتب إلى عماله أن يفرضوا لمن كان ابن خمس عشرة سنة. ومن فئ كان دون ذلك فاجعلوه في العيال.

"Rasulullah shallallaahu 'alaihi wa sallam menunjukku untuk ikut serta dalam perang Uhud, yang ketika itu usiaku empat belas tahun. Namun beliau tidak memperbolehkan aku. Dan kemudian beliau menunjukku kembali dalam perang Khandaq, yang ketika itu usiaku telah mencapai lima belas tahun. Beliau pun memperbolehkanku".

Naafi' berkata: "Aku datang kepada 'Umar bin 'Abdil-'Aziz yang ketika itu menjabat sebagai khalifah, lalu aku beri tahu tentang hadits tersebut. Kemudia ia berkata : 'Sungguh ini adalah batasan antara kecil dan besar'. Maka 'Umar menugaskan kepada para pegawainya untuk mewajibkan bertempur kepada orang yang telah berusia lima belas tahun, sedangkan

\footnotetext{
${ }^{24}$ Ibnu Al Himmam Al Hanafi, Syarah Fathul Qodir, Juz 8, h. 276

${ }^{25}$ Ibnu Hazm, Almuhalla, h. 119
} 
usia di bawahnya mereka tugasi untuk mengurus keluarga orang-orang yang ikut berperang" (HR. Al-Bukhari)

Namun, hadits ini pun tidak menunjukkan secara sharih bahwa usia lima belas tahun adalah batas usia balig. Hadits ini masih mengandung kemungkinan bahwa pelarangan Nabi shallallaahu 'alaihi wa sallam bukan karena faktor balig, namun karena masih kecilnya Ibnu 'Umar sehingga tidak dipandang mempunyai kemampuan/kecakapan untuk berperang. Ini terlihat dari ijtihad 'Umar bin 'Abdil-'Aziz yang hanya menandakan usia tersebut sebagai batas besar dan kecil untuk ikut berperang. Bukan balig dan tidak balig.

Pendapat yang rajih dalam permasalahan ini adalah tidak ada batasan usia tertentu untuk balig. Dan inilah pendapat yang diikutkan Ibnu Al Qayyim rahimahullah, dimana beliau berkata:

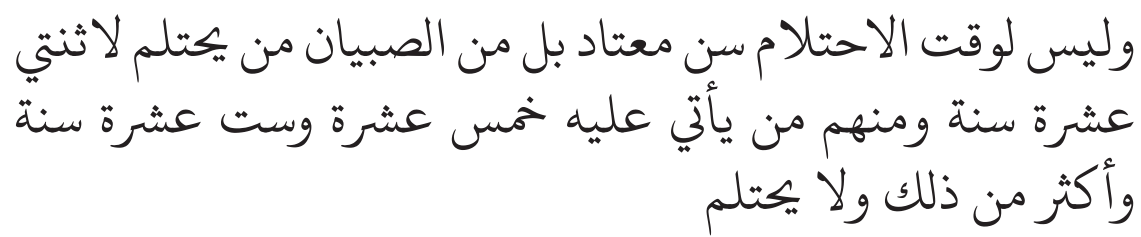

"Untuk waktu ihtilaam tidak ada batas usianya, bahkan anak-anak yang berusia dua belas tahun bisa ihtilaam. Ada juga yang sampai lima belas tahun, enam belas tahun, dan seterusnya namun belum ihtilaam" (Tuhfatul-Maudud h. 208).

Kemudian beliau melanjutkan:

وقال داود وأصحابه لا حد له بال إنما هو الاحتلام وهذا قول قوي "Dawud (Adh-Dhahiriy) dan shahabat-shahabatnya berkata: 'Tidak ada batasan tertentu untuk usia balig. Batas yang benar hanyalah ihtilam'. Ini adalah pendapat yang kuat".

\section{b. Tanda-tanda balig untuk perempuan antara lain:}

Adapun tanda balignya anak perempuan bisa sama seperti laki-laki, namun ditambah dengan keempatnya, yaitu haidl, berkembangnya alat-alat untuk berketurunan, serta membesarnya buah dada. Para ulama telah ijma' bahwasannya haidl merupakan tanda balig bagi seorang wanita. Al-Haafidh berkata: 


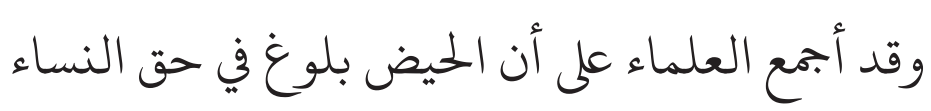

"Para ulama telah sepakatijma' bahwasannya haid merupakan tanda balig bagi wanita"26

Batas usiabalig bagi anak laki-laki dan perempuan adalah ibtilam. Khusus, bagi anak perempuan, atau ia telah mengalami haidl. Namun apabila ia sulit mengetahui apakah orang tersebut telah ibtilam (atau bagi anak perempuan ia terlambat haidl - atau bahkan tidak mengalami haidl sama sekali), maka tanda balignya diambil dari tumbuhnya rambut kemaluan.

Bila anak sudah mengalami salah satu tanda di atas, maka ia telahbalig yang dengan itu ia telah sampai pada usia taklif. Wajib baginya mengerjakan ibadah dan seluruh amalan wajib. Adapun sebelum itu, maka perintah hanyalah sebagai pembiasaan dan menjadikannya suka.

\section{Hukum Adat}

Hukum adat mempunyai cara lain untuk menetapkan apakah seseorang telah dewasa dan cakap untuk bertindak. Biasanya orang dianggap dewasa setelah menikah atau meninggalkan rumah keluarga, bisa dengan mencar., memasuki ruang tersendiri dalam keluarga dan mulai hidup mandiri. Batas dewasa seringkali diukur menurut keadaan yang ada, bersifat faktual. Usia dewasa mulai sejak ia bukan lagi bocah (huiskind). ${ }^{27} \mathrm{Di}$ Jawa Barat, ukuran yang dipakai dalam Hukum Adat adalah apakah orang itu telah "kuat gawe", artinya sudah bekerja, sudah bisa mengurus harta bendanya dan keperluan-keperluannya sendiri, sudah bisa mandiri. ${ }^{28}$ Ukuran kuat gawe juga dipakai oleh MA dalam keputusannya.$^{29}$ Hukum adat tidak memakai ukuran sekian banyak tahun yang telah dilalui seseorang tetapi berpatokan pada apa yang secara riil tampak, apakah ia masih bocah atau mandiri.

\footnotetext{
${ }^{26}$ Ibnu Hajar Al Asqolani, Fathul Bari, Juz 5, h. 277

27 B. Ter Haar, Beginselen en Stelsel van het Adatrecht, terjemahan, Jakarta, J.B. Wolters Groningen, 1950, h. 140.

${ }^{28}$ Soepomo, Hukum Perdata Adat Jawa Barat, terjemahan Nani Soewondo, Cetakan Kedua, Djambatan 1982, h. 22.

${ }^{29}$ Lihat putusan MA 2 Nopember 1976 No. 601 K/Sip/1976, di muat dalam RY MA RI, jilid II, h. 24 .
} 


\section{Putusan Pengadilan}

Pengadilan tidak konsisten dengan patokan umur dewasa. Ada yang berpegangan kepada ukuran 21 tahun, seperti pada:

1. PN Jakarta Pusat No. 1138/Pdt.P/1987/PN.JKT.PST tanggal 22 Desember 1987,

2. MA No. 59 K/AG/2007 tanggal 6 Juni 2007,

3. PA Malang No. 482/Pdt.G/2008/PA.Mlg tanggal 22 Mei 2008,

4. PA Wonosari No. 0432/Pdt.G/2008/PA. Wno tanggal 5 Agustus 2008,

5. MA No. $95 \mathrm{~K} / \mathrm{AG} / 2009$ tanggal 17 April 2009,

6. MA No. $294 \mathrm{~K} / \mathrm{AG} / 2009$ tanggal 16 Juni 2009,

7. PT Palembang kpts No. 41/1975 PT Perdata.

Di dalam keputusan-keputusan lain Pengadilan berpegang kepada usia dewasa 18 tahun, antara lain dalam putusan:

1. PN Jakarta Utara No. 1530/Pdt/1987/PN.Jakut tanggal 5 Nopember 1987 ,

2. MA No. 477/K/Sip/1976 tanggal 13 Oktober 1976.

Sehingga, sekalipun putusan-putusan pengadilan menggunakan ukuran kwantitas umur untuk penentuan dewasa tetapi kepastian berapa usia dewasa masih terdapat perbedaan dan ketidak seragaman batasnya.

\section{Pokok-Pokok Pendapat Mazhab Hukum dan Tokoh-Tokohnya}

Beberapa Mazhab yang dikenal dalam Ilmu Hukum adalah:

\section{Mazhab Hukum Alam}

Mazhab Hukum Alam diungkapkan oleh Aristoteles, Thomas Aquinas dan Hugo Grotius. Menurut Aristoteles, hukum alam adalah suatu hukum yang berlaku selalu dan di mana-mana karena berhubungan dengan aturan alam. Hukum itu tidak pernah berubah, tidak pernah lenyap, dan berlaku dengan sendirinya. Hukum Alam dibedakan dengan hukum positif, yang seluruhnya tergantung dari ketentuan manusia.

\section{Mazhab Formalistis (Positifisme)}

Jhon Austin menganggap hukum sebagai suatu sistem yang logis, tetap dan bersifat tertutup. Kelsen dalam ajaran hukum murninya 
menyatakan bahwa hukum tidak boleh dicampuri oleh masalahmasalah politik, kesusilaan, sejarah, kemasyarakatan, dan etika. Juga tidak boleh dicampuri oleh masalah keadilan. Keadilan menurut Kelsen adalah masalah ilmu politik.

\section{Mazhab Historis}

Friedrich Carl Von Savigny menyatakan bahwa hakikat dari sistem hukum menurut Savigny adalah sebagai pencerminan jiwa rakyat yang mengembangkan hukum itu. Semua hukum berasal dari adat istiadat dan kepercayaan bukan berasal dari pembentuk undang-undang. Sir Henry Maine mengatakan bahwa masyarakat ada yang "statis" dan ada yang "progresif". Masyarakat progresif adalah masyarakat yang mampu mengembangkan hukum melalui tiga cara, yaitu fiksi, equity, dan perundang-undangan.

\section{Mazhab Utilitarianism}

Tokoh mazhab ini adalah Jeremy Bentham dan Rudolph von Jhering. Bentham mengemukakan pembentuk hukum harus membentuk hukum yang adil bagi segenap masyarakat secara individual. Rudolph von Jhering menyatakan hukum merupakan suatu alat bagi masyarakat untuk mencapai tujuannya. Hukum adalah sarana untuk mengendalikan individu-individu agar tujuannya sesuai dengan tujuan masyarakat di mana mereka menjadi warganya. Hukum merupakan suatu alat yang dapat dipergunakan untuk melaksanakan perubahanperubahan sosial.

\section{Mazhab Sociological Jurisprudence}

Tokoh mazhab ini adalah Eugen Erlich dan Roscoe Pound. Menurut Erlich, pusat gaya tarik perkembangan hukum tidak terletak pada perundang-undangan, tidak pula pada ilmu hukum, melainkan di dalam masyarakat sendiri. Ajaran berpokok pada pembedaan antara hukum positif dengan hukum yang hidup. Dengan kata lain, hukum positif hanya akan efektif apabila selaras dengan hukum yang hidup dalam masyarakat.

Menurut Roscoe Pound, hukum harus dipandang sebagai suatu lembaga kemasyarakatan yang berfungsi untuk memenuhi kebutuhan-kebutuhan sosial, dan adalah tugas ilmu hukum untuk mengembangkan suatu kerangka dengan mana kebutuhan-kebutuhan sosial dapat terpenuhi secara maksimal. Pound juga menganjurkan 
untuk mempelajari hukum sebagai suatu proses (law in action), yang membedakan dengan hukum yang tertulis (law in the books).

\section{Mazhab Realisme Hukum}

Tokoh yang terkenal dalam aliran ini adalah Hakim Agung Oliver Wendel Holmes, Jerome Frank, dan Karl Liewellyn. Kaum realis berdasarkan pemikirannya pada suatu konsepsi radikal mengenai proses peradilan. Menurut mereka, hakim lebih layak disebut sebagai pembuat hukum daripada menemukannya. Hakim harus selalu melakukan pilihan, asas apa yang akan diutamakan dan pihak mana yang akan dimenangkan. Pokok-pokok pendekatan kaum realis antara lain hukum adalah alat untuk mencapai tujuan-tujuan sosial dan hendaknya konsepsi hukum itu menyinggung hukum yang berubahubah dan hukum yang diciptakan oleh pengadilan. ${ }^{30}$

\section{Penutup}

Sebagai kesimpulan dari tulisan ini adalah, bahwa Hukum Perdata, Hukum Pidana dan Hukum Ketatanegaraan memandang usia dewasa bagi seseorang berbeda-beda batasan dan sanksinya atau tindakan hukumnya jika melakukan suatu perbuatan yang dapat menimbulkan akibat hukum tertentu. Namun batasan yang digunakan adalah ukuran kwantitas yang jelas. Sudut pandang disiplin hukum lain yang juga berbeda memandang usia dewasa bagi seseorang dikatakan cakap hukum, misalkan sudut pandang Hukum Islam dan Hukum Adat. Sebagian besar Hukum Islam dan Hukum Adat melihat batasan Dewasa dari ciri-ciri fisik bukan dari sisi kwantitas umur, walaupun dari beberapa pendapat atau daerah (Hukum Adat) yang menggunakan batasan dewasa berdasarkan usia (Dalam Masyarakat Adat Batak. Pada umumnya anak yang sudah berusia 17 atau 18 tahun dianggap cakap bertindak: MA 1 Juni 1955 No. 53 K/Sip/1952, dimuat dalam RY MA RI, h. 175). Sedangkan batasan dewasa dalam putusan pengadilan menggunakan ukuran kwantitas, walaupun belum ada keseragaman berapa batas usia/umur seseorang dikatakan dewasa. Dalam penggunaan istilah "dewasa" pun terkadang digunakan istilah "belum cukup umur" dan "anak"

${ }^{30}$ Diambil dan diringkas dari berbagai buku Filsafat Hukum, antara lain tulisan; Prof. Otje Salman, Prof. A. Sidharta, Prof. Zainuddin Ali, Andre Ata Ujan, Hans Kelsen "Teori Hukum Murni” terjemahan, dll. 
dalam berbagai literatur dan perundang-undangan secara berbeda-beda

Terkait dengan Mazhab Hukum dalam penentuan batasan dewasa, sekalipun dalam tulisan tulisan ini menampilkan 6 mazhab, namun yang terasa sangat berpengaruh dalam mazhab hukum yang terbanyak adalah Mazhab Positivisme dan Mazhab Historis serta Sociological Jurisprudence yang mempengaruhi penggunaan batasan Dewasa. Hukum Perdata, Hukum Pidana, Hukum Ketatanegaraan dipengaruhi oleh Mazhab Positivisme hukum dikarenakan merupakan hukum positif dan membutuhkan kepastian dalam tataran pelaksanaan, sedangkan Hukum Islam dan Hukum Adat dipengaruhi oleh Mazhab Historis dan Sociological Jurisprudence. Dalam konteks Negara Indonesia berlakunya Hukum Perdata, Hukum Pidana dan Hukum Ketatanegaraan dilihat dari waktu dan ruang lingkup/tempat (meminjam bahasa Prof. Ahmad Sanusi), maka waktu berlakunya terbatas namun ruang lingkupnya luas, sedangkan Hukum Adat dan Hukum Islam waktu berlakunya tidak terbatas sepanjang masih dianut oleh masyarakat, hidup dan berlaku ditengah-tengah masyarakat, adapun ruang lingkup berlaku terbatas (wilayah tertentu).

Dalam tataran praktis (produk pengadilan), mengarah kepada mazhab positivisme, yaitu para hakim mendasarkan dewasa dengan mengikuti dan menerapkan ketentuan dalam pasal 330 KUHPerdata dan Pasal 47 dan 50 UU Nomor 1 Tahun 1974, namun ketika menyatakan kondisi di bawah umur, para hakim tanpa menjelaskan dasar hukum atau parameter apa yang digunakan oleh hakim. Hal ini menunjukkan kecenderungan tidak menggunakan mazhab manapun. ${ }^{31}$

\section{Pustaka Acuan}

Al Hanafi, Ibnu Al Himmam, Syarah Fathul Qodir, ttp. th. Juz 8

Amir, Syarifuddin. Ushul Figh Jilid 1. Jakarta: PT. Logos Wacana Ilmu. 2000

, Kaidah-kaidah Hukum Islam (Ilmu Ushulul Fiqh), Jakarta:PT. Raja Grafindo Persada, 2000

Bukhari, Shahih Bukhari, Bairut: Daar Fikr, 1981

${ }^{31}$ Lihat Skripsi Nurmillah mahasiswa Nonreguler Prodi SAS Konsentrasi Peradilan Agama tentang "Dispensasi Nikah", tahun 2011. 
Ibnu Hazm, Almuhalla, Kairo: Daar al- Ma’arif, 1997

Kamil, Ahmad dan Fauzan, H.M. Fauzan, Hukum Perlindungan dan Pengangkatan Anak di Indonesia, Jakarta: PT. Raja Grafindo Persada, 2008

Kansil, Pengantar Ilmu Hukum, Jakarta: Balai Pustaka, 1999.

Khallaf, Abdul Wahhab Khallaf, Ilmu Ushul Fiqh, Semarang: Toha Putra Group, 1994,

Kurdi, Muliadi Kurdi, Ushul Fiqh, Aceh: Lembaga Naskah Aceh (Nasa), 2015

Lubis , M. Solly, Asas-Asas Hukum Tata Negara, tp, 1972

Moeljatno, Kitab Undang-undang Hukum Pidana, Jakarta: Bumi Aksara, 1996

Muslim, Shahih Muslim, Bairut: Daar Fikr, 1981

Prist, Darwan Prist, Hukum Anak Indonesia, Bandung: PT. Citra Aditya Bakti, 2003

Soepomo, Hukum Perdata Adat Jawa Barat, terjemahan Nani Soewondo, Cetakan Kedua, Djambatan 1982, h. 22.

Ter Haar ,B, Beginselen en Stelsel van het Adatrecht, terjemahan, Jakarta, J.B. Wolters Groningen, 1950

Undang-Undang Pemilihan Umum, Surabaya: Kesindo Utama, 2008 